\title{
Effect of grazing management strategies on the yield and nutritional value of Marandu grass in the semiarid of Brazil
}

\section{Efeito de estratégias de manejo do pastejo na produtividade e valor nutricional do capim-Marandu no semiárido brasileiro}

\begin{abstract}
Maria Catiane Araújo Silva Veloso'; Eleuza Clarete Junqueira de Sales; Flávio Pinto Monção ${ }^{3 *}$; Vicente Ribeiro Rocha Júnior2; Virgílio Mesquita Gomes²; Dorismar David Alves²; Sidnei Tavares dos Reis"; João Paulo Sampaio Rigueira²; Amanda Maria Silva Alencar¹; Ignacio Aspiazú ${ }^{2}$
\end{abstract}

\section{Highlights}

The low intensity (LI) rotational grazing resulted in higher forage mass production.

The LI rotational grazing resulted in higher potentially digestible forage mass.

The LI rotational grazing resulted in higher digestible nutrients pre-grazing.

The LI improve the nutrients intake by cows.

\begin{abstract}
The objective of this study was to evaluate the effects of two grazing management strategies on structural, productive and nutritional parameters of Marandu grass (Urochloa brizantha cv. Marandu). A completely randomized block design with two pasture management strategies and eight replications (blocks) was used. The grazing management strategies were: (1) low intensity rotational grazing (LI), with a pre-grazing sward height of $40 \mathrm{~cm}$ and a post-grazing sward height of $24 \mathrm{~cm}$, i.e., a defoliation intensity of 50\%; (2) High intensity rotational grazing $(\mathrm{HI})$, with a pre-grazing sward height of $40 \mathrm{~cm}$ and a post-grazing sward height of $10 \mathrm{~cm}$ ( $\pm 70 \%$ defoliation intensity). Pastures were sampled before and after grazing for estimation of forage mass, forage accumulation rate, structural characteristics, nutritional value and dry matter intake.

1 Students of Animal Science Master's Course Postgraduate Program in Animal Science, Universidade Estadual de Montes Claros, UNIMONTES, Janaúba, MG, Brazil. E-mail: amariacatiane@yahoo.com; amandaalencar604@gmail. com

2 Profs. Drs., Postgraduate Program in Animal Science, UNIMONTES, Janaúba, MG, Brazil. E-mail: eleusa.sales@ unimontes.br; vicente.rocha@unimontes.br; virgilio.gomes@unimontes.br; dorismar.alves@unimontes.br; joao. rigueira@unimontes.br; ignacio.aspiazu@unimontes.br

3 Prof. and Researcher PNPD/Capes, Postgraduate Program in Animal Science, UNIMONTES, Janaúba, MG, Brazil. E-mail: moncaomoncao@yahoo.com.br

4 Prof. Dr., Universidade Federal de Minas Gerais, UFMG, Montes Claros, MG, Brazil. E-mail: satcreis@gmail.com

* Author for correspondence
\end{abstract}

Received: Sept. 11, 2020 - Approved: Mar. 25, 2021 
The LI strategy resulted in higher dry matter production than HI before (18.33\%) and after grazing (49.06\%), increasing pre-grazing forage density by $13.21 \%(P<0.05)$. The production of potentially digestible dry matter was highest $(P<0.05)$ in LI strategy $(21.3 \%$ before and $39.6 \%$ after grazing, respectively). Higher post-grazing green forage mass (45\%) increased the residual crude protein in LI. The LI management strategy increased forage mass production and can be used in Marandu grass pastures.

Key words: Cattle. Degradability. Morphology. Sward height. Urochloa brizantha.

\section{Resumo}

Objetivou-se por meio deste trabalho avaliar os efeitos de duas estratégias de manejo do pastejo sobre os parâmetros estruturais, produtivos e nutricionais do capim-Marandu (Urochloa brizantha cv. Marandu). O delineamento experimental foi em blocos casualizados com duas estratégias de manejo da pastagem e oito repetições (blocos). As estratégias de manejo do pastejo foram: (1) pastejo rotacional menos intensivo (LI), com altura do pasto pré-pastejo de $40 \mathrm{~cm}$ e altura do pasto pós-pastejo de $24 \mathrm{~cm}$, ou seja, intensidade de desfolha de 50\%; (2) pastejo rotativo mais intensivo (HI), com altura do pasto pré-pastejo de $40 \mathrm{~cm}$ e altura do pasto pós-pastejo de $10 \mathrm{~cm}( \pm 70 \%$ densidade de desfolha). As pastagens foram amostradas antes e após o pastejo para estimativa da massa de forragem, taxa de acúmulo de forragem, características estruturais, valor nutricional e consumo de matéria seca. A estratégia LI resultou em maior produção de matéria seca do que $\mathrm{HI}$ antes (18,33\%) e após pastejo (49,06\%), aumentando a densidade de forragem prépastejo em 13,21\% ( $P<0,05)$. A produção de matéria seca potencialmente digestível foi maior $(P<0,05)$ na estratégia LI (21,3\% antes e 39,6\% após o pastejo, respectivamente). Maior matéria seca verde total póspastejo (45\%) aumentou a proteína bruta residual em LI. A estratégia de manejo da LI aumentou a produção em massa de forragem e pode ser utilizada em pastagens de capim-Marandu.

Palavras-chave: Altura de dossel. Degradabilidade. Gado. Morfologia. Urochloa brizantha.

\section{Introduction}

Pasture is the primary and most economical source of nutrients for domestic ruminants (Barbero et al., 2020). Thus, it is necessary understand pasture-based systems do consider the plant-animal interface, which involves understanding the grazing conditions and their interference with animal performance. Usually, the objective of the rotational grazing system is to harvest the maximum amount of forage possible per grazing cycle in order to maximize pasture utilization. However, animals may be forced to ingest low-quality forage in the lower stratum, which impairs an effective harvesting process and forage intake (Amaral et al., 2013).
Efficient and alternative management practice is to control pasture sward height and forage mass production (Koscheck et al., 2020). The frequency and intensity of grazing can be combined to monitor the beginning and end of the grazing period without negatively affecting structure and forage accumulation. According to Reis, Ruggieri, Oliveira, Azenha and Casagrande (2012), using sward height as a management criterion allows controlling the forage mass and favors the sustainability of pasture-based systems. In this context, Silva et al. (2013) have shown that it is possible to control the condition of tropical pastures by using grazing management strategies depending on pasture sward height. 
In predominantly tropical conditions, studies with different forage species using swardheightasamanagementstrategy(Amaral et al., 2013; Savian et al., 2018; Schons et al., 2021) were carried out in order to determine the optimum pasture structure for achieving the highest forage intake. The results showed that in order to maintain high forage intake, the defoliation intensity should not exceed $40 \%$ of the pre-grazing height. After this threshold, the forage intake decreases linearly with defoliation intensity and animal production by area increase. As a result, the post-grazing residual mass and total leaf area remaining will be high, favoring the quick recovery of the plant after defoliation. Moreover, it would allow increasing the number of grazing cycles and forage production in some species (i.e., Urochloa brizantha) (Barbero et al., 2012, 2015). However, in the semiarid region of Brazil, where there is irregularity in the amount and distribution of rainfall throughout the year (Monção et al., 2019; 2020), there is a need to evaluate strategies for defoliating Marandu grass in order to improve animal performance and by area. Given the above, we hypothesized that a less intensive rotational grazing promotes a better balance between individual and area performance in Marandu grass pastures.
Thus, the aim of this study was to evaluate the effect of two grazing management strategies ( $\mathrm{LI} \times \mathrm{HI}$ ) on the structural, productive and qualitative characteristics of Marandu grass (Urochloa brizantha cv. Marandu).

\section{Material and Methods}

The study was approved by the Ethics Committee on Animal Use and Welfare at Universidade Estadual de Montes Claros (Protocol No. 167/2018).

The experiment was conducted in the municipality of Janaúba, MG, Brazil (1547'50"S latitude and $43^{\circ} 18^{\prime} 31^{\prime \prime} \mathrm{W}$ longitude, altitude 516 m), from November 2017 to November 2018. According to Köppen's classification, the region has a mesothermal, sub-humid and semiarid tropical climate (Aw) characterized by irregular rainfalls throughout the year and well-defined dry periods in the winter (Antunes, 1986). Climate data during the experimental period were obtained from the weather station of the INMET- Brazilian National Institute of Meteorology in Nova Porteirinha-MG, located $6 \mathrm{~km}$ away from the experimental area (Figure 1). 


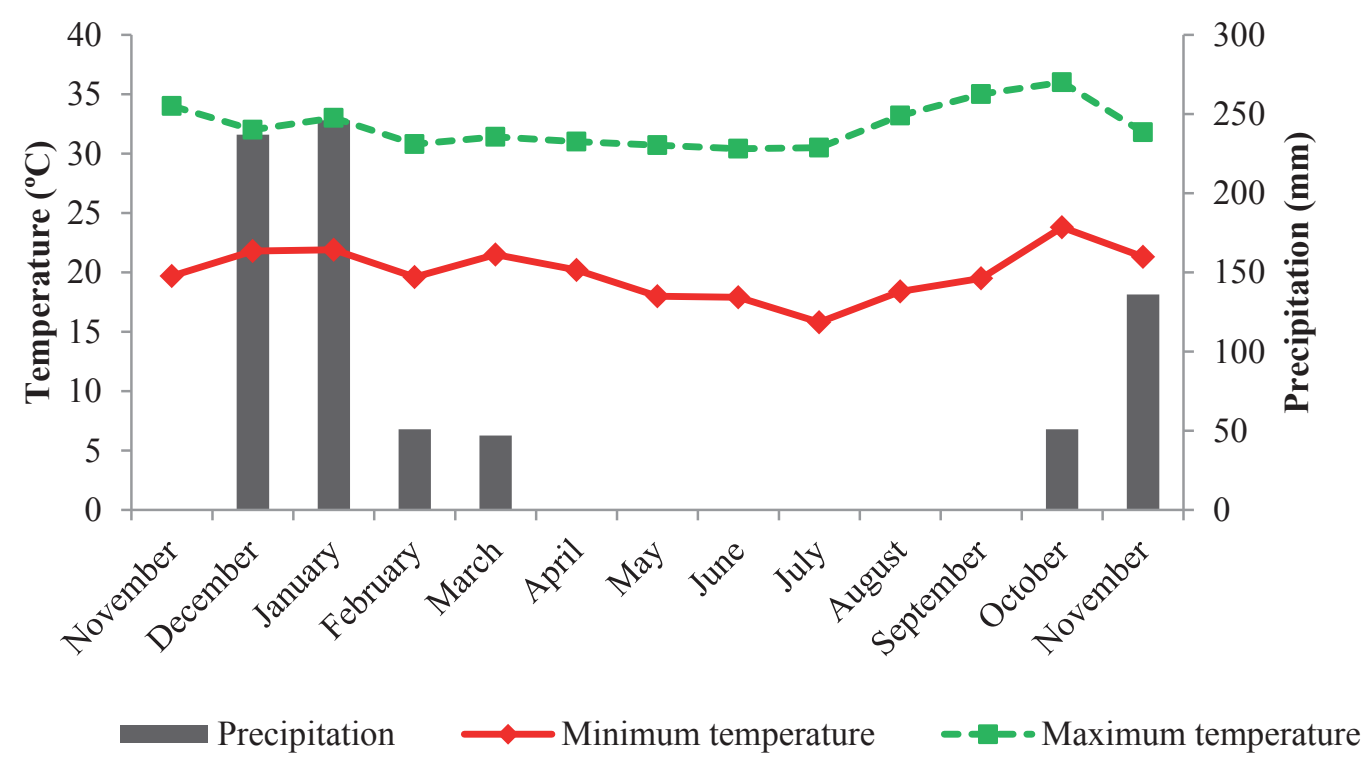

Figure 1. Climate data during the experimental period.

The experimental area consisted of a pasture of Urochloa brizantha cv. Marandu planted in 2012. The soil is classified as clayey eutrophic red-yellow latosol. Soil samples were taken at the $0-20 \mathrm{~cm}$ depth and had the following chemical characteristics: $\mathrm{pH}$ in $\mathrm{H}_{2} \mathrm{O}$ of $5.8 ; 2.3$ dag $\mathrm{kg}^{-1}$ of organic matter; $\mathrm{P}$ (Mehlich) of $3.6 \mathrm{dm}^{-3}, \mathrm{~K}$ (Mehlich) of $112 \mathrm{dm}^{-3}$, and $\mathrm{N}$ (Mehlich) of $0.1 \mathrm{mg} \mathrm{dm}^{-3} ; \mathrm{Ca}, \mathrm{Mg}$ and Al extracted with $1 \mathrm{~mol} \mathrm{~L}^{-1} \mathrm{KCl}$ of $3.7,1.5$ and 0.0 cmolc $\mathrm{dm}^{-3}$, respectively; $\mathrm{H}+\mathrm{Al} 2.9 \mathrm{cmolc}$ $\mathrm{dm}^{-3}$; sum of bases of $532 \mathrm{cmolc} \mathrm{dm}^{-3}$; cation exchange capacity of $8.3 \mathrm{cmolc} \mathrm{dm}-3$ and base saturation of $65 \%$. Overhead irrigation was used (flow rate $1.25 \mathrm{~m}^{3} / \mathrm{hour} ; 17.36 \mathrm{~mm} /$ hour; 20 meters range (radius)) for two hours. $2,4 \mathrm{D}$ herbicide was used to control invasive plants.

The soil was corrected based on the results of the soil chemical analysis. Dolomitic limestone was applied at a ratio of $500 \mathrm{~kg}$ per hectare - $100 \%$ total neutralizing value $(38 \%$ $\mathrm{CaO} ; 17 \% \mathrm{MgO}$ ) to raise the base saturation to
$80 \%$ as suggested by Santos, Primavesi and Bernardi (2010) for intensive grazing systems and to exploit the maximum productive potential of the forage plant. Phosphate fertilizer in the form of single superphosphate (18\% to $21 \% \mathrm{P}, 16 \% \mathrm{Ca}$ and $10 \%$ to $12 \%$ sulfur (S)) was applied once at a ratio of $50 \mathrm{~kg}$ $\mathrm{ha}^{-1} \mathrm{P}_{2} \mathrm{O}_{5}$ at the beginning of the experimental period, after the standardization cut. Nitrogen fertilization was performed after post-grazing periods at $200 \mathrm{~kg} \mathrm{ha}^{-1}$ urea nitrogen and $120 \mathrm{~kg}$ ha ${ }^{-1}$ potassium divided into four applications in the rainy season (December 2017, January, February and March 2018 for both treatments).

Experimental treatments corresponded to two grazing management strategies: (1) low intensity rotational grazing (LI), with a pre-grazing sward height of $40 \mathrm{~cm}$ and a post-grazing sward height of $24 \mathrm{~cm}$, i.e., a defoliation intensity of $50 \%$ according to the recommendations of Carvalho (2013); (2) High intensity rotational grazing $(\mathrm{HI})$, with a pre-grazing sward height of $40 \mathrm{~cm}$ and a 
post-grazing sward height of $10 \mathrm{~cm}$ aiming at maximum pasture utilization and low postgrazing residual height $( \pm 70 \%$ defoliation intensity). The treatments were allocated to experimental units $(200 \mathrm{~m} 2)$ in a randomized block design with eight replications. The possible variation in soil fertility was the blocking factor (eight blocks).

The total experimental area of 0.32 hectares was divided into 16 grazing areas of $200 \mathrm{~m} 2$ each, where each plot was considered as an experimental unit. At the beginning of the experimental period, the experimental pastures were grazed to an average height of $10 \mathrm{~cm}$ for standardization of the sward height, and then the target pre- and post-grazing sward heights were adopted.

A total of $12 \mathrm{~F} 1$ Holstein/Zebu cows with a mean body weight of $500 \pm 29 \mathrm{~kg}$ were used. Grazing was performed by the mob grazing technique for rapid defoliation (lasting from 4 to 20 hours). Each paddock was divided with an electric fence. As the animals grazed, sward height measurements were taken until the sward reached the 10 and $24 \mathrm{~cm}$ residue targets.

The average sward height was calculated as the average of 10 points per experimental unit using a graduated ruler $(\mathrm{cm})$, allowing for a range of $\pm 10 \%$ (Nantes et al., 2013). At each point, the sward height was determined as the distance from the soil to the most recent fully expanded leaf (pre-grazing) or to the tip of grazed leaves (post-grazing period). Measurements were taken every five days until the target sward height was reached. Defoliation intensity was evaluated by sward height measurements at intervals that ranged from 30 to 90 minutes during the grazing period. The grazing period in each management strategy lasted until the target post-grazing sward height was achieved.

Forage samples were cut at ground level before and after grazing using a $0.25 \mathrm{~m} 2$ (50x50 cm) metal quadrat at representative points of the pasture for determination of the forage mass production (FMP). Subsequently, the samples were weighed, and subsamples of approximately $500 \mathrm{~g}$ were taken, weighed and oven-dried at $55{ }^{\circ} \mathrm{C}$ for 72 hours to constant weight for evaluation of dry matter content and subsequent determination of DM production per hectare. These samples were used to determine the chemical composition and for the in situ degradability assay of the whole plant.

A second subsample was used to evaluate the pre- and post-grazing morphological composition of the pasture. The material was manually separated into leaf blades, stems (sheath + stem) and dead material (leaves or stems with more than $50 \%$ of dry area). After separation, all components were weighed and oven-dried at $55^{\circ} \mathrm{C}$ to constant weight for determination of the dry weight. After drying, the proportions of each component were determined and expressed as a percentage of the total dry weight.

The pre-and post-grazing green forage mass production (GFMP) were calculated by the sum of leaf blade mass and stem mass ( $\mathrm{kg} \mathrm{ha}^{-1}$ of DM). The leaf blade: stem ratio was obtained by dividing the leaf blade mass by the stem mass, while the pre- and post-grazing pasture density was calculated by dividing the total dry matter mass by the average sward height (Paulino, Detmann, \& Valadares, 2006).

The average forage accumulation rate ( $\mathrm{kg} \mathrm{ha}{ }^{-1}$ day $^{-1} \mathrm{DM}$ ) of each plot for each grazing cycle was calculated as the difference 
between the pre-grazing mass of one cycle and the post-grazing forage mass from the previous grazing cycle, divided by the number of days between samplings (Davies, Futhergill, \& Morgam, 1993).

The potentially digestible dry matter (pdDDM) was calculated using the equation: pdDDM (kg ha-1) = DMP* DDM; where: DMP $=$ dry matter production, in $\mathrm{kg} \mathrm{ha}^{-1}$; DDM = digestible dry matter (\%). Pasture DDM was obtained as described by Paulino et al. (2006): DDM = 0.98 (100 - \%NDF) + (\%NDF -\% iNDF). The iNDF (indigestible neutral detergent fiber) was estimated by in situ incubation of samples of both management strategies for 288 hours, according to Detmann et al. (2012).

The cows used in mob grazing were also used to evaluate forage dry matter intake. Forage intake (kg ha-1 DM) was calculated as the difference between total forage production ( $\left.\mathrm{kg}^{-1} \mathrm{DM}\right)$ in pre-grazing and postgrazing periods for both strategies. The results were multiplied by the total pasture area ( 0.16 hectares) and divided by the number of animals (12 cows) and the number of grazing days in each strategy to obtain the DM intake per animal per day (kg ha-1 animal day). Subsequently, the CP, NDF, and TDN intakes were calculated (McMeniman, 1997).

Whole-plant forage samples (average of ten cuts in the $\mathrm{HI}$ and eight cuts in the $\mathrm{LI}$ ) were oven-dried at $55^{\circ} \mathrm{C}$ to constant weight. After drying, each sample was divided into two aliquots: the first aliquot was ground in a Willey knife mill to pass a $1 \mathrm{~mm}$ screen for chemical composition analysis and the second aliquot was ground to pass a $2 \mathrm{~mm}$ screen for the in situ degradability assay.

Whole-plant samples were analyzed for dry matter (DM; 934.01), ash (942.05), ether extract (EE; 920.39), crude protein (CP; 978.04), neutral detergentfiber(NDF)andacid detergent fiber (ADF) contents were determined by the sequential method, according to procedures described by Detmann et al. (2012) using the TECNAL ${ }^{\circledR}$ TE-149 fiber analyzer (Piracicaba, SP, Brazil). Cellulose was solubilized in $72 \%$ sulfuric acid and lignin content was obtained by difference (Detmann et al., 2012). Total carbohydrate (TC) content was estimated by the equation: $\mathrm{TC}(\%)=100-(\mathrm{CP}+\mathrm{EE}+$ ash) and non-fibrous carbohydrates (NFC) were determined according to described by Detmann et al. (2012). Total digestible nutrients (TDN) were estimated by the formula: $\mathrm{TDN}=40.2625+0.1969^{*} \mathrm{CP}+0.4028^{*} \mathrm{NFC}+$ 1.903*EE - 0.1379*ADF (Weiss, 1998).

Four rumen-cannulated crossbred steers with an average weight of $500 \pm 45 \mathrm{~kg}$ were used to estimate the rumen degradation kinetics. The animals received $3.0 \mathrm{~kg}$ of concentrate in two equal amounts in the morning and afternoon, in addition to Marandu grass-based diets. The in situ degradability assay was performed using $7.5 \times 15 \mathrm{~cm}$ nonwoven fabric bags $\left(100 \mathrm{~g} \mathrm{~m}^{-2}\right.$; Pore size 50 microns), according to Valente et al. (2011); the number of samples was based on the sample size to bag surface area ratio of $20 \mathrm{mg} \mathrm{DM} /$ $\mathrm{cm}^{-2}$ (Valente et al., 2011).

The samples were placed in the ventral sac of the rumen for $0,3,6,12,24,48,72,96$, 120 and 144 hours in bags measuring $20 \times 30$ $\mathrm{cm}$ attached to a $1 \mathrm{~m}$ nylon cord with a lead weight of $100 \mathrm{~g}$ tied to one end. Therefore, the bags could move freely in the solid and liquid phases of the rumen. The bags were placed in reverse order, starting with the time of 144 hours. Samples for time 0 were placed in the rumen for five minutes. All samples were removed and washed in ice water to 
stop fermentation. Subsequently, the samples were oven-dried at $55 \mathrm{oC}$ to constant weight cooled in a desiccator, and weighed.

The residues in bags collected in the rumen were analyzed for DM and NDF contents. The percentage disappearance was calculated from the proportion of food remaining after ruminal incubation, while the NDF was analyzed according to the methods described by Detmann et al. (2012), without $\alpha$-amylase.

Data were adjusted to a non-linear regression model using the Gauss-Newton method using SAS software, version 9.0 (SAS Institute, Inc., Cary, NC, USA), according to the equation proposed by (Orskov \& McDonald, 1979): $\hat{Y}=a+b\left(1-e^{-c t}\right)$, where: $\hat{Y}=$ disappearance (\%) at time t; a = intercept of degradation curve when $\mathrm{t}=0$, which corresponds to the watersoluble fraction of the analyzed constituent; $b=$ is the slowly-degradable fraction; $a+b=$ potential degradation (PD) of the nutritional component analyzed when time is not a limiting factor; $\mathrm{c}=$ fractional degradation rate of disappearance of fraction $b$ in the rumen; $\mathrm{t}=$ incubation time. Once calculated, the coefficients $\mathrm{a}, \mathrm{b}$ and $\mathrm{c}$ were applied to the equation proposed by Orskov and Mcdonald (1979): $E D=a+(b x c / c+k)$, where: $E D=$ effective ruminal degradation of the analyzed nutritional component; $\mathrm{k}$ = passage rate. Ruminal passage rates were assumed to be $5 \% \mathrm{~h}^{-1}$.

The NDF degradability was estimated using the model of Mertens and Loften (1980): $\mathrm{Rt}=\mathrm{B} \times \mathrm{e}$-ct $+\mathrm{I}$, where $\mathrm{R}=\mathrm{NDF}$ remaining at time $\mathrm{t} ; \mathrm{B}=$ potentially digested insoluble fraction and $\mathrm{I}=$ indigestible fraction. After adjusting the NDF degradation equation, the fractions were standardized as proposed by
Waldo et al. (1972) using the equations: $\mathrm{Bp}=$ $\mathrm{B} /(\mathrm{B}+\mathrm{I}) \times 100 ; \mathrm{Ip}=\mathrm{I} /(\mathrm{B}+\mathrm{I}) \times 100$, where: $\mathrm{B}_{\mathrm{p}}$ $=$ standardized potentially digestible fraction (\%); Ip = standardized indigestible fraction (\%); $\mathrm{B}=$ potentially digestible insoluble fraction and $\mathrm{I}=$ indigestible fraction. The effective degradability (ED) of NDF was calculated according to the following model: $E D=(B p \times c) /$ $(c+k)$, where $B p$ is the standardized potentially digestible fraction (\%).

Data on plant structure, productivity, chemical composition and feed intake was analyzed as a completely randomized block design with two treatments and eight blocks. Data were subjected to analysis of variance using PROC GLM of SAS. Significant means were compared by the $F$ test with $\alpha=0.05$. The following statistical model was used: Yijk $=\mu+\tau i+B j+\varepsilon i j k$, where Yijk is the response variable; $\mu$ is the overall mean; $T$ is the effect of treatment ( $i=1$ and 2); $B$ is the effect of block; and $\varepsilon$ is the random error.

Data relative to in situ degradability were analyzed as a split-plot randomized complete block design with two treatments (plots), ten incubation times (subplots) and four blocks. Animals were blocked by body weight. Data were subjected to analysis of variance using the GLM procedure of SAS, with $\alpha=0.05$ according to the model: $Y$ ijk $=\mu+$ $\tau i+$ Time $j+\tau i x$ Time $j+\varepsilon i j k$, where: Yijk is the response variable; $\mu$, the overall mean; $\tau i$, the fixed effect of treatment applied to plot $i$, with $i$ $=1$ and 2; Time $j$, fixed effect of incubation time $\mathrm{j}$ to treatment the random effect from animal k; Ti x Time j, the interaction between treatment $\mathrm{i}$ and time j; $\varepsilon i \mathrm{jk}$, the random error with mean 0 and variance $\sigma^{2}$. 


\section{Results and Discussion}

The number of grazing cycles in Marandu grass pastures were different between grazing management strategies. The $\mathrm{LI}$ and $\mathrm{HI}$ allowed ten and eight cuts (grazing cycles/year), respectively. The pre-grazing sward heights were 41.9 and $40.8 \mathrm{~cm}$, while in the post-grazing period it was 23.9 and 12.1 $\mathrm{cm}$ for $\mathrm{LI}$ and $\mathrm{HI}$ strategies, respectively. There was a significant effect $(P<0.05)$ of pasture management strategy on FMP, green forage mass production (GFMP), pasture density, leaf blade:stem ratio, potentially digestible FMP (pdFMP) and forage accumulation rate. The $\mathrm{HI}$ was superior to LI only for leaf blade:stem ratio and forage accumulation rate. The proportions of leaf blade, stem and dead material were not affected by pasture management strategies, averaging 44.57; 36.43 and $18.99 \%$, respectively (Table 1 ).

\section{Table 1}

Structural and productive characteristics of pre-grazing Marandu grass pasture under two grazing management strategies

\begin{tabular}{|c|c|c|c|c|}
\hline \multirow[b]{2}{*}{ Item } & \multicolumn{2}{|c|}{ Strategies $^{1}$} & \multirow[b]{2}{*}{ SEM } & \multirow[b]{2}{*}{ P-value } \\
\hline & $\begin{array}{l}\text { Low intensity } \\
\text { (LI) }\end{array}$ & $\begin{array}{l}\text { High intensity } \\
\text { (HI) }\end{array}$ & & \\
\hline Forage mass production $\left(\mathrm{t} \mathrm{ha}^{-1}\right)$ & $11.62 \mathrm{a}$ & $9.82 b$ & & \\
\hline Green forage mass production ( $\mathrm{t} \mathrm{ha}{ }^{-1} \mathrm{DM}$ ) & $9.39 a$ & $7.98 \mathrm{~b}$ & 0.26 & 0.006 \\
\hline Volume density (t ha-1 $\mathrm{cm}^{-1} \mathrm{DM}$ ) & $0.277 \mathrm{a}$ & $0.241 \mathrm{~b}$ & 0.09 & 0.016 \\
\hline Leaf (\% DM) & 42.56 & 46.59 & 1.49 & 0.061 \\
\hline Stem (\% DM) & 38.53 & 34.34 & 1.75 & 0.096 \\
\hline Senescent material (\% DM) & 18.92 & 19.07 & 1.35 & 0.936 \\
\hline Leaf: Stem ratio & $1.11 \mathrm{~b}$ & $1.36 \mathrm{a}$ & 0.06 & 0.001 \\
\hline pdDMP (t ha-1) & $8.70 \mathrm{a}$ & $6.85 b$ & 1.93 & 0.001 \\
\hline Accumulation Rate (kg ha-1 day $\left.^{-1} \mathrm{DM}\right)$ & $87.17 \mathrm{~b}$ & $137.31 \mathrm{a}$ & 6.40 & 0.001 \\
\hline
\end{tabular}

Means followed by distinct letters on the line differ from each other by the $\mathrm{F}$ test at $5 \%$ probability.

SEM: standard error of the mean; P: probability.

DM: dry matter; pdFMP: Potentially digestible forage mass production.

${ }^{1} \mathrm{LI}$ - Pre-grazing and post-grazing sward height of $40 \mathrm{~cm}$ and $24 \mathrm{~cm}$, respectively (defoliation intensity of $\left.50 \%\right)$. $\mathrm{HI}$ - Pregrazing and post-grazing sward height of $40 \mathrm{~cm}$ and $10 \mathrm{~cm}$, respectively (defoliation intensity of $\pm 70 \%$ ).

The FMP, pdDMP and GFMP in the post-grazing period were higher in $\mathrm{LI}$ than in $\mathrm{HI}$ strategy $(\mathrm{P}<0.05)$. Pasture density, leaf proportion, stem proportion, dead material proportion and leaf blade: stem ratio were similar between treatments $(P>0.05)$, with means of $0.380 ; 23.31 ; 48.72 ; 27.95$ and 0.48 , respectively (Table 2 ).
The contents of ash, ADF and lignin were higher, while those of $\mathrm{CP}, \mathrm{OM}, \mathrm{EE}$ and TDN were lower in the pre-grazing period in pastures managed under the LI strategy compared with the $\mathrm{HI}(\mathrm{P}<0.05)$. There was no difference between strategies $(P>0.05)$ for DM, NDF, hemicellulose, TC and NFC contents, 
with means of 300; 689; 285; 816 and $126 \mathrm{~g}$ $\mathrm{kg}^{-1} \mathrm{DM}$, respectively (Table 3 ).

There was no difference between strategies for ash, hemicellulose, lignin and total carbohydrates in the post-grazing period $(P>0.05)$, with means of $106 ; 288 ; 575$ and 845 , $57 \mathrm{~g} \mathrm{~kg}^{-1} \mathrm{DM}$, respectively (Table 4). Pastures managed under the LI strategy had higher values of $\mathrm{CP}, \mathrm{NDF}, \mathrm{ADF}$ and $\mathrm{EE}$ and lower values of DM, TDN and NFC compared with the HI strategy $(\mathrm{P}<0.05)$.
Fraction "a" was highest in $\mathrm{HI}$ pastures $(\mathrm{P}<0.05)$. There were no significant differences between treatments for fraction " $b$ ", fraction "c", ED, uF and ruminal degradation of DM in the pre-grazing period ( $P>0.05)$, with means of $52.78 ; 1.94 ; 74.03 ; 34.57$ and $25.96 \%$, respectively (Table 5). However, the dry matter disappearance rate of the soluble fraction was similar between strategies. No significant differences were observed for the in situ ruminal degradability of NDF in the pre-grazing period $(P>0.05)$, with means of $69.99 ; 1.40$; 15.06 and $30 \%$ for Bp, fraction "c", ED and uF, respectively.

\section{Table 2}

Structural and productive characteristics of post-grazing Marandu grass pasture under two grazing management strategies

\begin{tabular}{|c|c|c|c|c|}
\hline \multirow[b]{2}{*}{ Item } & \multicolumn{2}{|c|}{ Strategies $^{1}$} & \multirow[b]{2}{*}{ SEM } & \multirow[b]{2}{*}{ P-value } \\
\hline & $\begin{array}{l}\text { Low intensity } \\
\text { (LI) }\end{array}$ & $\begin{array}{l}\text { High intensity } \\
\text { (HI) }\end{array}$ & & \\
\hline Forage mass produtction $\left(\mathrm{t} \mathrm{ha}^{-1}\right)$ & $9.07 \mathrm{a}$ & $4.62 \mathrm{~b}$ & 0.24 & 0.001 \\
\hline Green forage mass production ( $\mathrm{t} \mathrm{ha}^{-1} \mathrm{DM}$ ) & $6.29 \mathrm{a}$ & $3.46 \mathrm{~b}$ & 0.28 & 0.001 \\
\hline Volume density (t ha-1 $\left.\mathrm{cm}^{-1} \mathrm{DM}\right)$ & 0.38 & 0.38 & 0.02 & 0.718 \\
\hline Leaf (\% DM) & 22.22 & 24.40 & 2.09 & 0.464 \\
\hline Stem (\% DM) & 51.13 & 46.32 & 2.56 & 0.189 \\
\hline Senescent material (\% DM) & 26.64 & 29.27 & 1.16 & 0.117 \\
\hline Leaf: Stem ratio & 0.43 & 0.53 & 0.03 & 0.120 \\
\hline $\operatorname{pdFMP}\left(\mathrm{t} \mathrm{ha}^{-1}\right)$ & $5.41 \mathrm{a}$ & $3.27 \mathrm{~b}$ & 0.23 & 0.001 \\
\hline
\end{tabular}

Means followed by distinct letters on the line differ from each other by the $\mathrm{F}$ test at $5 \%$ probability.

SEM: standard error of the mean; P: probability.

DM: dry matter; pdFMP: Potentially digestible forage mass production.

${ }^{1} \mathrm{LI}$ - Pre-grazing and post-grazing sward height of $40 \mathrm{~cm}$ and $24 \mathrm{~cm}$, respectively (defoliation intensity of $50 \%$ ). $\mathrm{HI}$ - Pregrazing and post-grazing sward height of $40 \mathrm{~cm}$ and $10 \mathrm{~cm}$, respectively (defoliation intensity of $\pm 70 \%$ ). 


\section{Table 3}

Chemical composition of Marandu grass pre-grazing under two grazing management strategies

\begin{tabular}{ccccc}
\hline & \multicolumn{2}{c}{ Strategies $^{1}$} & & \\
\cline { 2 - 4 } Item (g kg-1 DM) & $\begin{array}{c}\text { Low intensity } \\
(\text { LI) }\end{array}$ & $\begin{array}{c}\text { High intensity } \\
(\text { HI) }\end{array}$ & SEM & P-value \\
Dry matter & 307 & 293 & 10 & 0.340 \\
Ash & $119 \mathrm{a}$ & $114 \mathrm{~b}$ & 12 & 0.047 \\
Organic matter & $880 \mathrm{~b}$ & $886 \mathrm{a}$ & 2 & 0.047 \\
Crude protein & $88 \mathrm{~b}$ & $96 \mathrm{a}$ & 2 & 0.009 \\
Neutral detergent fiber & 698 & 682 & 7 & 0.087 \\
Acid detergent fiber & $417 \mathrm{a}$ & $392 \mathrm{~b}$ & 6 & 0.003 \\
Hemicellulose & 281 & 289 & 4 & 0.135 \\
Lignin & $44 \mathrm{a}$ & $37 \mathrm{~b}$ & 1 & 0.001 \\
Ether extract & $14 \mathrm{~b}$ & $16 \mathrm{a}$ & 1 & 0.001 \\
Total digestible nutrients & $422 \mathrm{~b}$ & $435 \mathrm{a}$ & 3 & 0.010 \\
Total carbohydrates & 818 & 814 & 3 & 0.310 \\
Non-fibrous carbohydrates & 119 & 132 & 6 & 0.184
\end{tabular}

Means followed by distinct letters on the line differ from each other by the $\mathrm{F}$ test at $5 \%$ probability.

SEM: standard error of the mean; P: probability.

DM- Dry matter

${ }^{1} \mathrm{LI}$ - Pre-grazing and post-grazing sward height of $40 \mathrm{~cm}$ and $24 \mathrm{~cm}$, respectively (defoliation intensity of $50 \%$ ). $\mathrm{HI}$ - Pregrazing and post-grazing sward height of $40 \mathrm{~cm}$ and $10 \mathrm{~cm}$, respectively (defoliation intensity of $\pm 70 \%$ ).

Fraction "a" was highest in HI pastures in the post-grazing period $(\mathrm{P}<0.05)$, although no significant differences $(P>0.05)$ were observed for fraction "b", fraction "c", ED and $u F$, with means of $47.51 ; 1.53 ; 65.06 ; 28.36$ and $34.92 \%$, respectively (Table 6).

Relative to the ruminal degradability of NDF, no significant differences were observed for Bp, fraction "c", ED and uF (P>0.05), with means of $56.02 ; 0.12 ; 10.54$ and $43.97 \%$, respectively. Forage intake was influenced by management strategies $(\mathrm{P}<0.05)$ (Table 7$)$. Animals grazing pastures managed under the $\mathrm{HI}$ strategy had higher intakes of DM, CP, NDF and TDN than those in LI pastures. 
Table 4

Chemical composition of post-grazing Marandu grass under two grazing management strategies

\begin{tabular}{|c|c|c|c|c|}
\hline \multirow[b]{2}{*}{ Item (g kg-1 DM) } & \multicolumn{2}{|c|}{ Strategies $^{1}$} & \multirow[b]{2}{*}{ SEM } & \multirow[b]{2}{*}{ P-value } \\
\hline & $\begin{array}{l}\text { Low intensity } \\
\text { (LI) }\end{array}$ & $\begin{array}{l}\text { High intensity } \\
(\mathrm{HI})\end{array}$ & & \\
\hline Dry matter & $452 b$ & $519 a$ & 1 & 0.001 \\
\hline Ash & 107 & 105 & 2 & 0.561 \\
\hline Organic matter & 893 & 895 & 2 & 0.561 \\
\hline Crude protein & $81 a$ & $72 b$ & 2 & 0.054 \\
\hline Neutral detergent fiber & 709 a & $678 b$ & 5 & 0.001 \\
\hline Acid detergent fiber & 419 a & $392 b$ & 5 & 0.001 \\
\hline Hemicellulose & 291 & 286 & 4 & 0.389 \\
\hline Lignin & 59 & 56 & 2 & 0.347 \\
\hline Ether extract & $11 \mathrm{a}$ & $9 \mathrm{~b}$ & 1 & 0.001 \\
\hline Total digestible nutrients & $426 \mathrm{~b}$ & $443 a$ & 2 & 0.001 \\
\hline Total carbohydrates & 842 & 849 & 3 & 0.073 \\
\hline Non-fibrous carbohydrates & $132 b$ & $172 \mathrm{a}$ & 5 & 0.001 \\
\hline
\end{tabular}

Means followed by distinct letters on the line differ from each other by the $\mathrm{F}$ test at $5 \%$ probability.

SEM: standard error of the mean; P: probability.

DM- Dry matter

${ }^{1} \mathrm{LI}$ - Pre-grazing and post-grazing sward height of $40 \mathrm{~cm}$ and $24 \mathrm{~cm}$, respectively (defoliation intensity of 50\%). $\mathrm{HI}$ - Pregrazing and post-grazing sward height of $40 \mathrm{~cm}$ and $10 \mathrm{~cm}$, respectively (defoliation intensity of $\pm 70 \%$ ). 


\section{Table 5}

Ruminal degradability of dry matter and neutral detergent fiber of Marandu grass pre-grazing under two grazing management strategies

\begin{tabular}{|c|c|c|c|c|}
\hline \multirow[b]{2}{*}{ Item } & \multicolumn{2}{|c|}{ Strategies ${ }^{1}$} & \multirow[b]{2}{*}{ SEM } & \multirow[b]{2}{*}{ P-value } \\
\hline & $\begin{array}{l}\text { Low intensity } \\
\text { (LI) }\end{array}$ & $\begin{array}{l}\text { High intensity } \\
\text { (HI) }\end{array}$ & & \\
\hline \multicolumn{5}{|c|}{ Dry matter } \\
\hline Fraction a (\%) & $19.65 b$ & $22.84 a$ & 0.69 & 0.003 \\
\hline Fraction b (\%) & 53.14 & 52.42 & 1.95 & 0.795 \\
\hline Degradation Rate c $\left(\% \mathrm{~h}^{-1}\right)$ & 2.19 & 1.69 & 2.50 & 0.163 \\
\hline Potential degradability (\%) & 72.79 & 75.27 & 2.13 & 0.419 \\
\hline Effective degradability (\%) & 34.07 & 35.07 & 0.65 & 0.291 \\
\hline Indigestible fraction (\%) & 27.20 & 24.73 & 2.13 & 0.419 \\
\hline \multicolumn{5}{|c|}{ Neutral detergent fiber } \\
\hline Fraction Bp (\%) & 71.84 & 68.15 & 1.98 & 0.206 \\
\hline Degradation Rate c $\left(\% \mathrm{~h}^{-1}\right)$ & 1.44 & 1.37 & 0.16 & 0.779 \\
\hline Effective degradability (\%) & 15.16 & 15.02 & 0.62 & 0.873 \\
\hline Undegradable fraction (\%) & 31.84 & 28.16 & 1.98 & 0.206 \\
\hline
\end{tabular}

Means followed by distinct letters on the line differ from each other by the $\mathrm{F}$ test at $5 \%$ probability.

SEM: standard error of the mean; P: probability;

Fraction "a": soluble fraction; Fraction "b": insoluble and potentially degradable fraction; effective degradability $(\mathrm{k}=5 \%$ h-1); IF: indigestible fraction; Fraction Bp: standardized potential degradability.

${ }^{1} \mathrm{LI}$ - Pre-grazing and post-grazing sward height of $40 \mathrm{~cm}$ and $24 \mathrm{~cm}$, respectively (defoliation intensity of $50 \%$ ). $\mathrm{HI}$ - Pregrazing and post-grazing sward height of $40 \mathrm{~cm}$ and $10 \mathrm{~cm}$, respectively (defoliation intensity of $\pm 70 \%$ ).

Pasture sward height remained stable and within the target ranges for each management strategy ( $\mathrm{LI} \times \mathrm{HI}$ ). Defoliation intensity in LI pastures was $42.96 \%$ (from 41.9 to $23.9 \mathrm{~cm}$ ) and $70.34 \%$ in $\mathrm{HI}$ pastures (from
$40.8 \mathrm{~cm}$ to $12.1 \mathrm{~cm})$. Therefore, the number of grazing cycles in the $\mathrm{LI}$ grazing management strategy increased by $20 \%$ compared with the HI strategy. 


\section{Table 6}

Ruminal kinetics of dry matter and neutral detergent fiber of Marandu grass after grazing submitted to two grazing management strategies

\begin{tabular}{|c|c|c|c|c|}
\hline \multirow[b]{2}{*}{ Item } & \multicolumn{2}{|c|}{ Strategies $^{1}$} & \multirow[b]{2}{*}{ SEM } & \multirow[b]{2}{*}{ P-value } \\
\hline & $\begin{array}{l}\text { Low intensity } \\
\text { (LI) }\end{array}$ & $\begin{array}{l}\text { High intensity } \\
\text { (HI) }\end{array}$ & & \\
\hline \multicolumn{5}{|c|}{ Dry matter } \\
\hline Fraction a (\%) & $16.43 b$ & 18.68 a & 0.53 & 0.005 \\
\hline Fraction b (\%) & 46.76 & 48.26 & 1.29 & 0.422 \\
\hline Degradation Rate c $(\% \mathrm{~h}-1)$ & 1.50 & 1.56 & 1.60 & 0.782 \\
\hline Potential degradability (\%) & 63.19 & 66.94 & 1.45 & 0.079 \\
\hline Effective degradability (\%) & 27.55 & 29.18 & 0.56 & 0.063 \\
\hline Indigestible fraction (\%) & 36.80 & 33.05 & 1.45 & 0.079 \\
\hline \multicolumn{5}{|c|}{ Neutral detergent fiber } \\
\hline Fraction Bp (\%) & 57.67 & 54.38 & 1.67 & 0.169 \\
\hline Degradation Rate c $\left(\% \mathrm{~h}^{-1}\right)$ & 0.14 & 0.11 & 0.12 & 0.140 \\
\hline Effective degradability (\%) & 11.45 & 9.63 & 0.71 & 0.080 \\
\hline Undegradable fraction (\%) & 42.33 & 45.62 & 1.67 & 0.169 \\
\hline
\end{tabular}

Means followed by distinct letters on the line differ from each other by the $\mathrm{F}$ test at $5 \%$ probability.

SEM: standard error of the mean; P: probability;

Fraction "a": soluble fraction; Fraction "b": insoluble and potentially degradable fraction; effective degradability (k $=5 \%$ h-1); IF: indigestible fraction; Fraction Bp: standardized potential degradability.

${ }^{1} \mathrm{LI}$ - Pre-grazing and post-grazing sward height of $40 \mathrm{~cm}$ and $24 \mathrm{~cm}$, respectively (defoliation intensity of $50 \%$ ). $\mathrm{HI}$ - Pregrazing and post-grazing sward height of $40 \mathrm{~cm}$ and $10 \mathrm{~cm}$, respectively (defoliation intensity of $\pm 70 \%$ ).

\section{Table 7}

Nutrient intake by F1 Holstein/Zebu cows kept in Marandu grass pasture submitted to two grazing management strategies

\begin{tabular}{ccccc} 
& \multicolumn{2}{c}{ Strategies $^{1}$} & & \\
\cline { 2 - 3 } Item & $\begin{array}{c}\text { Low intensity } \\
\text { (LI) }\end{array}$ & $\begin{array}{c}\text { High intensity } \\
\text { (HI) }\end{array}$ & SEM & P-value \\
Dry matter & $9.84 \mathrm{~b}$ & $13.31 \mathrm{a}$ & 0.94 & 0.011 \\
Crude protein & $0.83 \mathrm{~b}$ & $1.23 \mathrm{a}$ & 0.07 & 0.001 \\
Neutral detergent fiber & $6.90 \mathrm{~b}$ & $9.09 \mathrm{a}$ & 0.66 & 0.023 \\
Total Digestible Nutrients & $4.15 \mathrm{~b}$ & $5.80 \mathrm{a}$ & 0.41 & 0.006
\end{tabular}

Means followed by distinct letters on the line differ from each other by the $\mathrm{F}$ test at $5 \%$ probability. SEM: standard error of the mean; P: probability.

${ }^{1} \mathrm{LI}$ - Pre-grazing and post-grazing sward height of $40 \mathrm{~cm}$ and $24 \mathrm{~cm}$, respectively (defoliation intensity of 50\%). HI - Pregrazing and post-grazing sward height of $40 \mathrm{~cm}$ and $10 \mathrm{~cm}$, respectively (defoliation intensity of $\pm 70 \%$ ). 
The moderate defoliation intensity in the LI strategy $(42.96 \%)$ suggested that only the upper stratum of the pasture was removed (Oliveira et al., 2015; Cardoso et al., 2020). Consequently, the post-grazing heights in LI pastures were proportionally high, which allowed rapid pasture recovery, more grazing cycles and shorter resting periods for reaching the target pre-grazing height in the subsequent grazing cycle (Rodrigues et al., 2014). The pregrazing FMP was $18.33 \%$ higher in LI than in $\mathrm{HI}$ strategy, with a total production of $11.62 \mathrm{t}$ ha $^{-1}$ of DM, which in turn increased the forage density by $13.21 \%$. This higher productivity combined with low pasture intensity (42.96\%) increased the post-grazing FMP by $49.06 \%$, or an additional of $4.45 \mathrm{t} \mathrm{ha}^{-1}$ of DM compared with the $\mathrm{HI}$ strategy. This can be explained by the higher GFMP in $\mathrm{LI}$ management and also by the intense defoliation in $\mathrm{HI}$ strategy (70.34\%) that reduced the residual forage mass, represented in this study by the low post-grazing GFMP. Consequently, the time required for forage recovery increased and the number of grazing cycles reduced. The pdFMP in pre- and post-grazing were $21.3 \%$ and $39.6 \%$ higher in LI than in HI strategy (8.70 and 6.85 vs. 5.41 and 3.27 t ha $^{-1}$, respectively). This may provide greater forage availability, allowing maximum dry matter intake during grazing. The GFMP, which corresponds to leaves and stems, was $15 \%$ and $45 \%$ higher in $\mathrm{LI}$ than in $\mathrm{HI}$ strategy in the pre- and postgrazing periods, respectively. These values are above the $1.11 \mathrm{t} \mathrm{ha}^{-1}$ suggested as a limiting factor for grazing production, which could influence forage selection and animal performance (Barbero et al., 2012, 2015).

Regarding the forage chemical composition, the DM contents of the whole plant, leaf and stem in the post-grazing period were $12.91,25.60$ and $14.46 \%$ higher in $\mathrm{HI}$ than in LI strategy, respectively. Intensively grazed pastures had higher leaf: stem ratio before and after grazing compared with LI pastures. The leaf: stem ratio is of great importance to animal production and forage plant management as it is directly related to forage intake. According to Van Soest (1994), the higher the leaf: stem ratio, the higher the nutritional value of the forage. Leaves are rich in crude protein but low in fiber; consequently, leaves are more digestive than other plant fractions.

The different grazing management strategies affected the protein content of the forage. In the pre-grazing period, the $\mathrm{CP}$ content was $8.33 \%$ higher in $\mathrm{HI}$ than in LI strategy, which may be associated with the higher leaf: stem ratio observed in the $\mathrm{HI}$ management. On the other hand, the $\mathrm{CP}$ content in the post-grazing period was $11.11 \%$ higher in $\mathrm{LI}$ than in $\mathrm{HI}$ management (81 and $72 \mathrm{~g} \mathrm{~kg}^{-1} \mathrm{DM}$, respectively), which probably occurred due to the higher amount of residual green dry matter in the forage sward in $\mathrm{LI}$ pastures.

The TDN content is approximately $55 \%$ in forages and is used to express the energy content of feeds (Van Soest, 1994). In this study, TDN values in the pre- and post-grazing periods were close to $45 \%$ regardless of the grazing management strategy. In the pregrazing period, the TDN content increased by 2.99\% in $\mathrm{HI}$ compared with the $\mathrm{LI}$ treatment, which can be explained by the decrease in ADF obtained in the HI strategy. Intensively grazed pastures had higher NFC content in the post-grazing period (23.26\%) compared with LI pastures, which may be related to the reduction in NDF, CP, EE and ash contents. 
The evaluation of fibrous constituents of forages is essential for the formulation of ruminant diets due to their correlation with dry matter intake and feed digestibility. There was no difference between strategies for NDF content in the pre-grazing period. Both NDF contents were above the minimum required of $55-60 \%$ in forage-based diets (Van Soest, 1994; Monção et al., 2019; 2020; Queiroz e al., 2021). The pre-grazing ADF and lignin contents, and post-grazing NDF and ADF contents were $5.99 ; 15.91 ; 4.37$ and $6.44 \%$ higher in LI strategy than in $\mathrm{HI}$, respectively.

Although the values of the fibrous fraction were above those recommended by Van Soest (1994), they did not affect forage degradability in both treatments, what is interesting for tropical grasses. Only the DM degradability of fraction "a" was influenced by the different management strategies, which was $13.97 \%$ and $12.05 \%$ higher in $\mathrm{HI}$ than in $\mathrm{LI}$ strategy in the pre- and post-grazing periods, respectively. Fraction "a" corresponds to the primary source of energy for rumen microorganisms, leading to a reduction in lag time. The proportion of fraction "a" in early-harvested forages is smaller due to the lower soluble carbohydrate content at reduced harvesting ages compared with more advanced growth ages.

No significant differences were observed for the ruminal degradability of NDF, showing behavior similar to that of DM degradability. Fiber digestibility in forages is not constant for all animals or all feeding conditions, but the primary source of variation stems from differences in structure, chemical composition and maturity stage (Van Soest, 1994; Monção et al., 2019). However, although the different sward heights in the present study affected some structural and chemical characteristics, they did not significantly affect the ruminal degradation of DM and NDF, which may favor animal performance.

The different grazing management strategies affected the forage intake of animals. Pasture structural characteristics can influence the forage intake. The lower DM intake of animals grazing pastures managed under the LI strategy may be related to the lower leaf: stem ratio observed in this management. The high proportion of dead material and/or stem may limit animal selectivity and forage intake even when DM production is high. The intakes of DM; CP; NDF and TDN were 26.07; 32.52; 24.09 and $28.45 \%$ higher in animals grazing pastures managed under the $\mathrm{HI}$ strategy compared with those in LI management, respectively. The higher DM intake observed in animals grazing pastures managed under the $\mathrm{HI}$ strategy is probably related to the higher $\mathrm{CP}$ and TDN content compared with LI strategy, which in turn increased the intake of these nutrients.

The NDF intake was $24.09 \%$ higher in $\mathrm{HI}$ strategy compared to the LI strategy, mean of $6.9 \mathrm{~kg} /$ day. Similar DM intake would be expected between strategies when repletion is the limiting factor, given that there was no difference in NDF content between strategies, and that the NDF content is negatively correlated with DM intake (Detmann, Valente, Batista, \& Huhtanen, 2014). Thus, it can be inferred that forage intake may have been controlled by factors external to the animal, such as plant structural characteristics. Borges et al. (2019) evaluated different tropical forages on the productive performance of $\mathrm{F} 1$ Holstein $x$ Zebu cows in feedlot. The authors concluded that the NDF intake varied from 6.17 to $9.94 \mathrm{~kg} /$ day without changing milk yield (mean of $12.57 \mathrm{~kg} /$ day). Rabelo et al. (2020) and Ramos et al. (2021) also evaluated different 
tropical grass silage (i.e., forage sorghum silage, biomass sorghum silage) with NDF content above $60 \%$ in the diet of $F 1$ Holstein $x$ Zebu cows and found no change in milk yield.

\section{Conclusion}

The intensive rotational grazing strategy in Marandu grass pastures increased forage productivity without compromising pasture renewal due to the higher dry matter production but similar nutritional quality to that of less intensive rotational grazing strategy.

\section{Acknowledgments}

The authors would like to thank the Foundation for Research Support of Minas Gerais (FAPEMIG); the State University of Montes Claros (Unimontes); Instituto Nacional de Ciência e Tecnologia (INCT - Ciência Animal, Brazil); and the National Council for Scientific and Technological Development (CNPq) for assistance with scholarships/research. This study was financed in part by the Coordination for the Improvement of Higher Education Personnel - Brazil (CAPES) - Finance Code 001. The authors would like to thank the undergraduate students for their contribution towards the accomplishment of the research.

\section{References}

Amaral, M. F., Mezzalira, J. C., Bremm, C., Trindade, J. K. da, Gibb, M. J., Silva, R., \& Carvalho, P. C. F. (2013). Sward structure management for a maximum short-term intake rate in annual ryegrass. Grass and Forage Science, 68(1), 271-277. doi: 10.1111/j.1365-2494.2012.00898.x
Antunes, F. Z. (1986). Caracterização climática do Estado de Minas Gerais. Informe Agropecuário, 12(139), 9-13. Recupeado de http://189.80.133.54:8080/consulta/bu sca?b=ad\&id=6697\&biblioteca=vazio\&bus ca=assunto:Clima\&qFacets=assunto:Clima \&sort=\&paginacao=t\&paginaAtual=1

Barbero, R. P., Malheiros, E. B., Aguilar, N. M., Romanzini, E. P., Ferrari, A. C., Nave, R. G.,... Reis, R. A. (2020). Supplementation level increasing dry matter intake of beef cattle grazing low herbage height. Journal of Applied Animal Research, 48(1), 28-33. doi: 10.1080/09712119.2020.1715985

Barbero, R. P., Malheiros, E. B., Araújo, T. L. R., Nave, R. L. G., Mulliniks, J. T., Berchielli, T. T.,... Reis, R. A. (2015). Combining Marandu grass grazing height and supplementation level to optimize growth and productivity of yearling bulls. Animal Feed Science and Technology, 209(1), 110-118. doi: 10.10 16/j.anifeedsci.2015.09.010

Barbero, R. P., Barbosa, M. A. A. F., Castro, L. M., Ribeiro, E. L. A., Mizubuti, I. Y., Massaro, F. L., Jr., \& Silva, L. D. F. da. (2012). Comportamento ingestivo de novilhos de corte sob diferentes alturas de pastejo do capim Tanzânia.Semina:CiênciasAgrárias, 33(2), 3287-3294. doi: 10.5433/1679-03 59.2012v33Supl2p3287

Borges, L. D. A., Rocha, V. R., Jr., Monção, F. P., Soares, C., Ruas, J. R. M., Silva, F. V.,... Rabelo, W. O. (2019). Nutritional and productive parameters of Holstein/Zebu cows fed diets containing cactus pear. Asian-Australasian Journal of Animal Sciences, 32(9), 1373-1380. doi: 10.5713/ ajas.18.0584

Cardoso, A. S., Barbero, R. P., Romanzini, E. P., Teobaldo, R. W., Ongaratto, F., 
Fernandes, M. H. M. R.,... Reis, R. A. (2020). Intensification: a key strategy to achieve great animal and environmental beef cattle production sustainability in brachiaria grasslands. Sustainability, 12(16), 6656. doi: 10.3390/su12166656

Carvalho, P. C. F. (2013). Harry stobbs memorial lecture: can grazing behavior support innovations in grassland management? Tropical Grasslands-Forrajes Tropicales, 1(2), 137-155. doi: 10.17138/tgft(1)137155

Davies, D. A., Futhergill, M., \& Morgam, C. T. (1993). Assessment of contrasting perennial ryegrasses with and white clover, under continuous stocking in the uplands. 5. Herbage production, quality and intake in years 4-6. Grass and Forage Science, 48(1), 213-222. doi: 10.1111/j. 1365-2494.1993.tb01854.x

Detmann, E., Valente, E. E. L., Batista, E. D., \& Huhtanen, P. (2014). An evaluation of the performance and efficiency of nitrogen utilization in cattle fed tropical grass pastures with supplementation. Livestock Science, 162(1), 141-153. doi: 10.1016/j. livsci.2014.01.029

Detmann, E., Souza, M. A., Valadares, S. C., Fo., Queiroz, A. C., Berchielli, T. T., Saliba, E. O. S.,... Azevedo, J. A. G. (2012). Methods for food analysis. Visconde do Rio Branco. Suprema.

Koscheck, J. F. W., Romanzini, E. P., Barbero, R. P., Delevatti, L. M., Ferrari, A. C., Mulliniks, J. T.,... Reis, R. A. (2020). How do animal performance and methane emissions vary with forage management intensification and supplementation? Animal Production Science, 60(9), 1201-1209. doi: 10.1071/ AN18712
McMeniman, N. P. (1997). Methods of estimating intake of grazing animals. Anais do Simpósio Sobretópicos Especiais em Zootecnia, Juiz de Fora, MG, Brasil.

Mertens, D. R. \& Loften, J. R. 1980. The effects of starch on forage fiber digestion kinetics in vitro. Journal of Dairy Science, 63(9), 1437-46. doi: 10.3168/jds.S00220302(80)83101-8

Monção, F. P., Costa, M. A. M. S., Rigueira, J. P. S., Moura, M. M. A., Rocha, V. R. Jr., Mesquita, V. G.,... Chamone, J. M. A. (2019). Yield and nutritional value of BRS capiaçu grass at different regrowth ages. Semina Ciências Agrárias, 41(5), 745-755. doi: 10. 5433/1679-0359.2019v40n5p2045

Monção, F. P., Costa, M. A. M. S., Rigueira, J. P. S., Sales, E. C. J., Leal, D. B., Silva, M. F. P.,... Rocha. V. R. Jr. (2020). Productivity and nutritional value of BRS capiaçu grass (Pennisetum purpureum) managed at four regrowth ages in a semiarid region. Tropical Animal Health and Production, 52(1), 235-241. doi: 10.1007/s11250-019 $-02012-y$

Nantes, N. N., Euclides, V. P. B., Montagner, D. B., Lempp, B., Barbosa, R. A., \& Gois, P. O. (2013). Desempenho animal e características de pastos de capim piatã submetidos a diferentes intensidades de pastejo. Pesquisa Agropecuária Brasileira, 48(1), 114-121. doi: 10.1590/S0100-204X 2013000100015

Oliveira, A. P., Casagrande, D. R., Bertipaglia, L. M. A., Barbero, R. P., Berchielli, T.T., Ruggieri, A. C., \& Reis, R. A. (2015). Supplementation for beef cattle on Marandu grass pastures with different herbage allowances. Animal Production Science, 56(1), 1-8. doi: 10.10 71/AN14636 
Orskov, E. R., \& McDonald, J. (1979). The estimation of protein degradability in the rumen from incubation measurements weighted according to rate passage. Journal of Agriculture Science, 92(2), 499503. doi: $10.1017 / S 0021859600063048$

Paulino, M. F., Detmann, E., \& Valadares, S. C., Fo. (2006). Suplementação animal em pasto: energética ou protéica? Anais do Simpósio Sobre Manejo Estratégico da Pastagem, Viçosa, MG, Brasil, 3.

Queiroz, F. E., Rocha, V. R. Jr., Monção, F. P., Rigueira, J. P. S., Parrella, R. A. C., Rufino, L. D. A.,... Cordeiro, M. W. S. (2021). Effect of row spacing and maturity at harvest on the fermentative profile, aerobic stability, and nutritional characteristics of biomass sorghum (BRS 716) silage in the semiarid region of Brazil. Revista Brasileira de Zootecnia, 50(1), e20200254. doi: 10.37 496/rbz502020 0254

Rabelo, W. O., Rocha, V. R., Jr., Monção, F. P., Costa, N. M., Rigueira, J. P. S., Souza, B. P.,... Pires, D. A. A. (2020). Effect of different roughage sources associated banana pseudostem hay on the nutritional and behavioral parameters and performance of F1 Holstein/Zebu lactation cows. Tropical Animal Health and Production, 52(6), 3769-3780. doi: 10.1007/s11250020-02414-3

Ramos, J. C. P., Rocha, V. R., Jr., Monção, F. P., Parrela, R. A. C., Caxito, A. M., Cordeiro, M. W. S.,... Pires, D. A. A. (2021). Effect of replacing forage sorghum silage with biomass sorghumsilage in diets for $\mathrm{F} 1$ Holstein $\times$ Zebu lactating cows. Tropical Animal Health and Production, 53(1), 99111. doi: 10. 1007/s11250-020-02503-3
Reis, R. A., Ruggieri, A. C., Oliveira, A. A., Azenha, M. V., \& Casagrande, D. R. (2012). Suplementação como estratégia de produção de carne de qualidade em pastagens tropicais. Revista Brasileira de Saúde e Produção Animal, 13(3), 642655. doi: 10.1590/S1519-994020120003 00005

Rodrigues, R. C., Lana, R. D. P., Cutrim, J. A. A., Jr., Sanchês, S. S. C., Galvão, C. M. L., Sousa, T. V. R. D., \& Jesus, A. P. R. D. (2014). Acúmulo de forragem e estrutura do dossel do capim-xaraés submetido a intensidades de cortes. Revista Brasileira de Saúde e Produção Animal, 15(4), 815-826. doi: 10.1590/S1519-99402014000400002

Santos, P. M., Primavesi, O. M., \& Bernardi, A. C. C. (2010). Adubação de pastagens. In A. V. Pires (Ed.)., Bovinocultura de corte (pp. 459-472). Piracicaba: Fealq.

Savian, J. V., Schons, R. M. T., Marchi, D. E., Freitas, T. S., Silva, G. F., Neto, Mezzalira, J. C.,... Carvalho, P. C. F. (2018). Rotatinuous stocking: a grazing management innovation that has high potential to mitigate methane emissions by sheep. Journal of Cleaner Production, 186(1), 602-608. doi: 10.1016/j.jclepro.2018.03. 162

Schons, R. M. T., Laca, E. A., Savian, E. A., Mezzalira, J. C., Schneider, E. A. N., Caetano, L. A. M.,... Carvalho, P. C. F. (2021). 'Rotatinuous' stocking: An innovation in grazing management to foster both herbage and animal production. Livestock Science, 245(1), 1-8. doi: 10.1016/j.livsci. 2021.104406 
Silva, S. C. da, Gimenes, F. M. A., Sarmento, D. O. L., Sbrissia, A. F., Oliveira, D. E., Hernadez-Garay, A., \& Pires, A. V. (2013). Grazing behaviour, herbage intake and animal performance of beef cattle heifers on Marandu palisade grass subjected to intensities of continuous stocking management. Journal of Agricultural Science, 151(5), 727-739. doi: 10.1017/ S0021859612000858

Valente, T. N. P., Detmann, E., Queiroz, A. C., Valadares, S. C., Fo., Gomes, D. I., \& Filgueiras, J. F. (2011). Evaluation of rumen degradation profiles of forages using bags made from different textiles. Revista Brasileira de Zootecnia, 40(11), 2565-2573. doi: 10.1590/S1516-359820 11001100039
Van Soest, P. J. (1994). Ecologia nutricional do ruminante (2a ed.). Nova lorque, EUA: Imprensa da Universidade de Cornell.

Waldo, D. R.; Smith, L. W. \& Cox, L. E. 1972. Model of cellulose disappearance from the rumen. Journal of Dairy Science, 55(1), 125-9. doi.10.3168/jds.S0022-03 02(72)85442-0

Weiss, W. P. (1998). Estimating the available energy content of feeds for dairy cattle. Journal of Dairy Science, 81(3), 830-839. doi: 10.3168/jds.S0022-0302(98)75641-3 
